\title{
Synthesis of $l$-Methyl Acetic by Esterification $l$-Menthol and Acetic Anhydride with Variation of Time
}

\author{
Novia Suryani ${ }^{1 *}$, A Ghanaim Fasya ${ }^{2}$, Akyunul Jannah², Rurini Retnowati ${ }^{3}$ \\ ${ }^{1}$ Chemistry Education, Islamic State University of Mataram \\ ${ }^{2}$ Departement Chemistry, Faculty of Science and Technology, The State \\ Islamic University of Maulana Malik Ibrahim Malang \\ ${ }^{3}$ Departement of Chemistry Faculty of Mathematics and Science, University \\ Brawijaya \\ *Corresponding Author : noviasuryani@uinmataram.ac.id \\ Received: January,20,2020 /Accepted:June,29,2020 \\ doi: $10.24252 /$ al-kimia.v7i2.11965
}

\begin{abstract}
: l-methyl acetic is an ester with specific aroma that synthesized by reaction of lmenthol and acetic anhydride and useful in fragrance industry. This paper reports influenced variation of time reaction toward ester product and characteristics $l$ - methyl acetic based on TLC, FTIR, GC and GC-MS. Reaction using l-menthol, acetic anhydride and catalyst $\mathrm{H}_{2} \mathrm{SO}_{4} 98 \%$ in diethyl ether solvent at temperature $60{ }^{\circ} \mathrm{C}$ with variation of time reaction $(45,60,75,90,105$ minutes). The result of research is variation of time influence product with highest yield $88,43 \%$ for 90 minutes. Monitoring TLC achived $R_{f}$ of 0,82; analysis by FTIR achived specific wave number ester 1736,96 $\mathrm{cm}^{-1}$; analysis by GC achived $t_{r}$ of 14,82 minutes and analysis by GCMS achived $t_{r \text { was }} 16,13$ minutes with base peak $\mathrm{m} / \mathrm{z}$ which was 95 .
\end{abstract}

Keywords: esterification, l-methyl acetic, synthesis, variation of time.

\section{INTRODUCTION}

Menthol is a major component in peppermint oil that can be produced from the distillation of leaves Mentha x pipertits (Raharjo, 2013), with a distinctive aroma of peppermint and give effect to the taste. $l$-menthol compounds included monocyclic monoterpenes class (Moon, 2004) with the chemical formula $\mathrm{C}_{10} \mathrm{H}_{20} \mathrm{O}$ (Stolle and Hopf, 2009). Conversation $l$-menthol to ester can be form by reaction using acetic anhydride by esterification with sulfate acid as catalyst (Sastrohamidjojo, 2004). This reaction known as esterification Fischer (Carey, 2000).

Chasana research (2014), gained influence ratio mole from $l$ - menthol: acetic anhydride (2:1) with the highest yield $l$-methyl acetic $28,28 \%$ at temperature $60{ }^{\circ} \mathrm{C}$ for 60 minutes, but have not obtained information influence variation of time between $l$ menthol and acetic anhydride in esterification reaction to yield $l$-methyl acetic. So, in this study will reaction with variation of time for 45, 60, 75, 90, 105 minutes (Hikmah dan Zuliyana, 2010).

Variation of time provide information the influence the variation of time to yield of an ester to be obtained. Theoretically, increasing reaction time at Fischer esterification can increase the amount of product formed, this is caused by the increase in the intensity of collision between the reactants in the form of products (Fatmawati and Shakti, 2013).

\section{RESEARCH METHODS}




\section{Materials and Tools}

The tools used are refluxed with funnel $(250 \mathrm{~mL})$, 3-neck flask, chamber elucidation, thermometer, separating funnel $250 \mathrm{~mL}$, vacuum pump, hot plate, watch glass, vaporizer cup, oven, mortar, funnel glass, stir bar, spatula, drop pipette, measuring pipette $10 \mathrm{~mL}$, flask $100 \mathrm{~mL}$, flask $25 \mathrm{~mL}$, capillary tube, pycnometer $2 \mathrm{~mL}$, measuring pipette $5 \mathrm{~mL}$, beaker glass $250 \mathrm{~mL}$ and $500 \mathrm{~mL}$, universal $\mathrm{pH}$ paper, TLC plate GF254, tube vial, Atago Hand Refractometer, Chromatography Gas-Mass Spectroscopy (GCMS) Aglient 6980N Network GC System, Chromatography Gas HP 5890 and FTIR Varian 1000 Scimitar Series.

The materials used are $l$-menthol, acetic anhydride, diethyl ether $99,5 \%$, sulfate acid $98 \%$, ethanol $95 \%$, distilled water, sodium bicarbonate, magnesium sulfate heptahydrate, acetic ethyl, methanol and nitrogen gas $\left(\mathrm{N}_{2}\right)$.

\section{Procedure}

\section{Synthesis l-methyl Acetic}

A set of tools reflux prepared and assembled. $l$-menthol then weighed as much as $31.25 \mathrm{~g}(0,2$ mole). Then put in a 3 - neck flask which was equipped with a magnetic stirrer, condenser and heating. Further added diethyl ether solvents as $10.38 \mathrm{~mL}(0,1$ mole) in the 3 -neck flask and added as much as $9.45 \mathrm{~mL}$ of acetic anhydride $(0,1$ mole) drop by drop. Then the catalyst was added $\mathrm{H}_{2}-\mathrm{SO}_{4} 98 \%$ of $0.5 \mathrm{~mL}(0,1$ mole $)$ are per drop. Refluxed with variation of time :45; 60; 75; 90 and 105 minutes.

\section{Monitoring Synthesis Mixture by TLC}

Activation of the TLC plate silica GF254 use the oven for 20 minutes at $100{ }^{\circ} \mathrm{C}$. The next $l$-menthol and $l$-methyl acetic spotted at a distance of $1,0 \mathrm{~cm}$ from the bottom edge of the TLC plate and eluted using a capillary tube to a distance of $8.5 \mathrm{~cm}$. Eluent used is n-hexane and ethyl acetate in a ratio of 9:1 Then the plate is dried and sprayed with a solution of $5 \% \mathrm{H}_{2} \mathrm{SO}_{4}$ in methanol. After the plates dry and then heated on a hotplate to show two pieces of brownish yellow stains on the plate. $\mathrm{Rf}$ its calculated value and compared with $\mathrm{Rf}_{\mathrm{f}} l$-menthol 0,40 (Pelter, et al., 2008) and $l$-methyl acetic suspected to have $\operatorname{Rf}_{\mathrm{f}} 0,80$ to 0,83 (Chasana, et al., 2014).

\section{Separation Synthesis Mixed Result}

The results of the synthesis mixture is put into separating funnel $250 \mathrm{~mL} . \mathrm{pH}$ synthesized checked using universal $\mathrm{pH}$ paper. $\mathrm{NaHCO}_{3} 5 \%$ added in solution until $\mathrm{pH}$ up to $\mathrm{pH}$ distilled water $(\mathrm{pH}=5)$. Then the mixture was shaken and allowed for 5 minutes until the organic phase and aqueous phase separate apparent. Organic phase containing a mixture of compounds comprising ester compound $l$-methyl acetic, $l$ menthol and solvent diethyl ether while the water phase is composed of neutral salts. The organic phase is collected in glass beaker $250 \mathrm{~mL}$ and added $\mathrm{Mg}_{2} \mathrm{SO}_{4}$ anhydrous. Furthermore, the organic phase is separated from $\mathrm{MgSO}_{4}$ anhydrous by decanted carefully and slowly then accommodated in the tube vial. Nitrogen gas 
flowed on the surface and the bottom of the tube vial, weighed to constant weight. Having obtained a constant weight, closed tube vial using aluminum foil wrapped up tightly and stored in freezer.

\section{Characterization of Physical Properties Mixed Result Synthesis}

Characteristic of physical properties of the mixture of compounds synthesized (aroma and color). Determination of density performed by weighing as much as $2 \mathrm{~mL}$ of compounds synthesized using $2 \mathrm{~mL}$ pycnometer. Measured temperature of mixture synthesis result using a thermometer. The density value is calculated using the formula:

$$
\rho=\rho^{\prime}+k\left(T-T^{\prime}\right)
$$

The formula consists of $\mathrm{p}$ as density at $\mathrm{T}\left({ }^{\circ} \mathrm{C}\right), \rho^{\prime}$ as density at $\mathrm{T}^{\prime}\left({ }^{\circ} \mathrm{C}\right), \mathrm{k}$ is correction factor and $\mathrm{T}$ is temperature mixture synthesis

Determination refractive index of compound synthesized were determined by Atago Hand Refractometer. Before the measurement are made, cleaned first the tool refractometer with $95 \%$ ethanol and then calibrated using distilled water. Subsequently, the sample was dropped on the prism 2 drops. The reading of the refractive index of samples was made during light-dark boundary of the line right at the intersection of the prism. Refractive index values calculated by the formula:

$$
\mathrm{n}=\mathrm{n}^{\prime}+\mathrm{k}\left(\mathrm{T}-\mathrm{T}{ }^{\prime}\right)
$$

The formula consists of $\mathrm{n}$ as refractive index at $\mathrm{T}\left({ }^{\circ} \mathrm{C}\right)$, n' as refractive index at $\mathrm{T}^{\prime}\left({ }^{\circ} \mathrm{C}\right), \mathrm{k}$ as correction factor and $\mathrm{T}$ as temperature mixture synthesis

\section{Characterization by FTIR}

$l$-menthol, acetic anhydride, and $l$-methyl acetic dropped into the scouring $\mathrm{KBr}$ pellet. Furthermore $\mathrm{KBr}$ pellet is placed in the cell holder through which the light beam and made its IR spectrum at wave number range $4000-400 \mathrm{~cm}^{-1}$.

\section{Characterization by GC}

A total of $0.01 \mathrm{~mL}$ of $l$-menthol and $l$-methyl acetic injected into the inlet using syiringe GC HP 5890 instrument with temperature column and detector $250^{\circ} \mathrm{C}$, gas flow rate of $2 \mathrm{~mL} / \mathrm{min}$, FID detector. The data obtained in the form of a chromatogram. $\%$ Peak area is used to determine the ratio of constituent compounds synthesized by the following equation 3.

$$
\% \text { Rasio }=\frac{\% \text { area menthyl acetic }}{\% \text { area compounds }} 100 \%
$$

While the mass of $l$-methyl acetic research result obtained using the equation 4 .

$$
\text { Massa } l-\text { methyl acetic }=\frac{\% \text { area menthyl acetic }}{\% \text { area compounds }} m
$$


Furthermore, the yield of the compound $l$-methyl acetic research results obtained using the following equation 5 .

$$
\text { Yield of } l-\text { methyl acetic }=\frac{\text { mass menthyl acetic }}{\text { mass compounds }} X 100 \%
$$

\section{Characterization by $G C-M S$}

A total of $0,01 \mathrm{~mL}$ of $l$-menthol and $l$-methyl acetic using syringe injected into the GC-MS instrument inlet Aglient 6980N Network GC System with detector temperature at $300{ }^{\circ} \mathrm{C}$, gas flow rate of $1,3 \mathrm{~mL} / \mathrm{min}$, detector Aglient 5973 inert MSD, Data from instrument such as mass spectra GC-MS, further interpretation of spectral data and comparing the mass spectra of $l$-menthol and $l$-methyl acetic with the standards of library Willey version 7.0.

\section{RESULT AND DISCUSSION}

Results obtained by esterification of the compound in the form of a yellow liquid and a distinctive smell of mint with the results of the monitoring TLC chromatogram obtained in the form of two brownish yellow stains with a stain $I R_{f}=0,41$; while $R_{f}$ stain II $=0,82$ allegedly was $\mathrm{R}_{\mathrm{f}}$ product. Characterization of physical properties obtained density of $1,1055 \mathrm{~g} / \mathrm{ml}$ and the refractive index of 1,4426 . Characterization of the results of the synthesis mixture is done by FTI, GC, and GC-MS. IR spectral data indicate that the ester group $\mathrm{C}=\mathrm{O}$ stretching vibration at wavenumber $1736,96 \mathrm{~cm}^{-}$ ${ }^{1}$, C-O stretching vibration at wavenumber $1245,82 \mathrm{~cm}^{-1}$. Besides the $\mathrm{OH}$ stretching vibration at wave number $3454,03 \mathrm{~cm}^{-1}$ and C-O stretching vibration of secondary alcohols at wave number $1023,32 \mathrm{~cm}^{-1}$ shows that the results of the synthesis mixture still contains $l$-menthol.

Analysis by GC shows have been formed compound $l$-methyl acetic. Analysis of the result of the synthesis mixture with chromatogram obtained GC 2 peaks, peak I with $\operatorname{tr}_{r}=11,71$ minutes allegedly is $l$-menthol while peak II with $\operatorname{tr}_{r}=14,82$ minutes is suspected $l$-methyl acetic, the compound had tr longer than $l$-menthol is because it is nonpolar making it retained on the column. The following analysis of the data presented by GC against the constituent compounds synthesized as in Table 1.

Tabel 1. Yield (\%) of $l$-methyl acetic

\begin{tabular}{|c|c|c|c|c|}
\hline \multirow{2}{*}{$\begin{array}{c}\text { Time reaction } \\
\text { (minute) }\end{array}$} & $\begin{array}{c}\text { Peak } \\
\text { I }\end{array}$ & $\begin{array}{c}\text { Peak } \\
\text { II }\end{array}$ & $\begin{array}{c}\text { Peak } \\
\text { III }\end{array}$ & \multirow{2}{*}{$\begin{array}{c}\text { Yield } \\
\text {-methyl }\end{array}$} \\
\cline { 2 - 4 } & \multicolumn{3}{|c|}{$\%$ Area } \\
\hline 45 & 8,41 & 63,34 & 23,17 & 33,28 \\
\hline 60 & 9,06 & 56,70 & 32,02 & 47,37 \\
\hline 75 & 4,99 & 60,30 & 32,78 & 49,04 \\
\hline $\mathbf{9 0}$ & $\mathbf{6 , 3 2}$ & $\mathbf{3 0 , 4 5}$ & $\mathbf{6 0 , 3 1}$ & $\mathbf{8 8 , 4 3}$ \\
\hline 105 & 4,94 & 66,42 & 28,65 & 33,49 \\
\hline
\end{tabular}

Based the yield results in Table 1, show that the highest yield was obtained at reaction time 90 minutes which is $88.43 \%$. This shows that with increasing reaction time given will increase the yield of the synthesis product, but with a decrease in the yield explain that if a reactant which have reacted has reached the optimum time to collide then 
the extension reaction time will not yield more (Ozgul and Turkey, 2002 in : Widyawati, 2007 in Kasim, 2012). Then, the highest yield results is analyzed using GC-MS. GC-MS analysis of the obtained two peaks, peak I with $\mathrm{tr}_{\mathrm{r}}=13.30$ minutes suspected $l$-menthol produce fragment ion peak at $\mathrm{m} / \mathrm{z}=29,41,55,71,81,95,109$, 123, 138, 147, 155, 191, 207, 281.

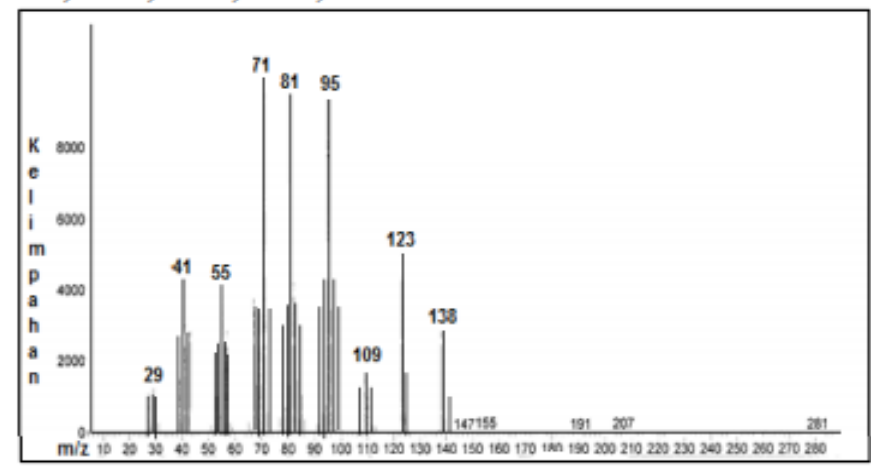

Figure 1. Spectra mass 1-menthol

The secondary alcohol, the peak was observed due to release of $\mathrm{H}$ atom shown in Figure 2 .

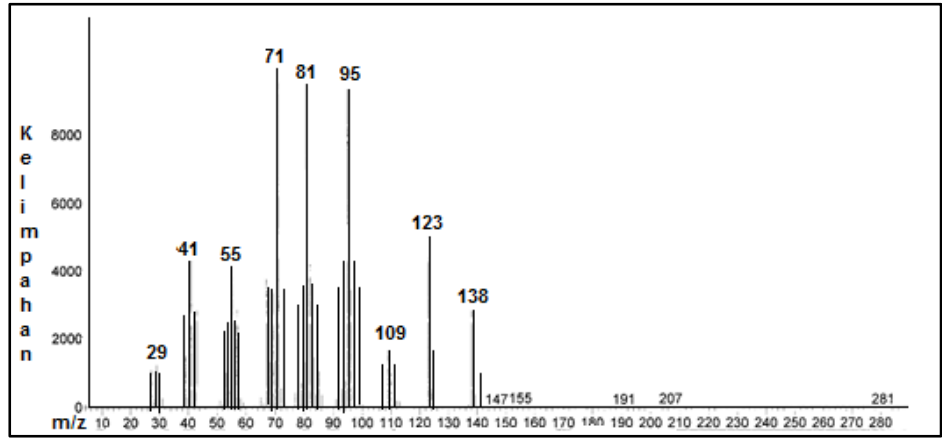

Figure 2. Release of $\mathrm{H}$ atom on secondary alcohol (Silverstein, dkk., 2005).

While $\mathrm{tr}_{\mathrm{r}}=16,13$ minutes assumed $l$-methyl acetic resulted in fragment ion peak at $\mathrm{m} / \mathrm{z}$ $=29,37,43,55,61,67,73,81,87,95,103,109,115,123,138,147,155,165,183,207$.

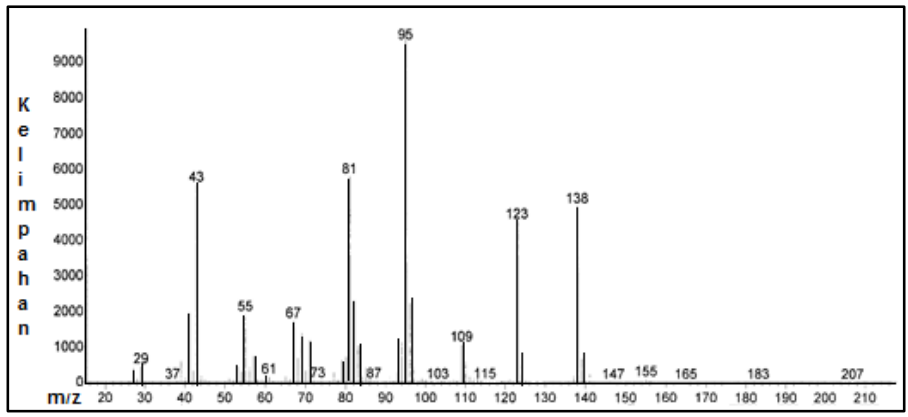

Figure 3. Spectra mass $l$-methyl acetic (90 minutes) 
Fragment with $\mathrm{m} / \mathrm{z}=198$ is ion molecule of $l$-methyl acetic with chemical formula $\mathrm{C}_{12} \mathrm{H}_{22} \mathrm{O}_{2}$ does not appear. Because ester with spesific alcohol dominant easily remove acetic acid so molecular ion peak not detectable (Silverstein, et. al 2005).

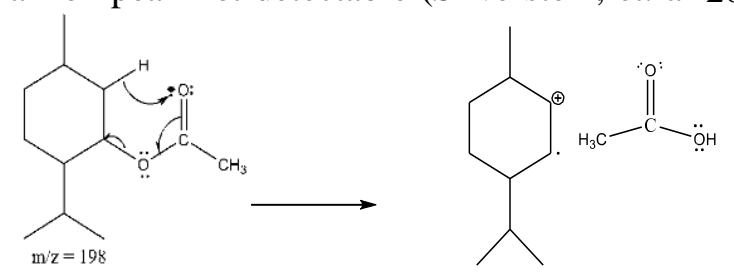

Figure 4. Rearrangement Mc Lafferty (Silverstein, et al., 2005).

While the base peak obtained $\mathrm{m} / \mathrm{z}=95$ shown in Figure 5 .

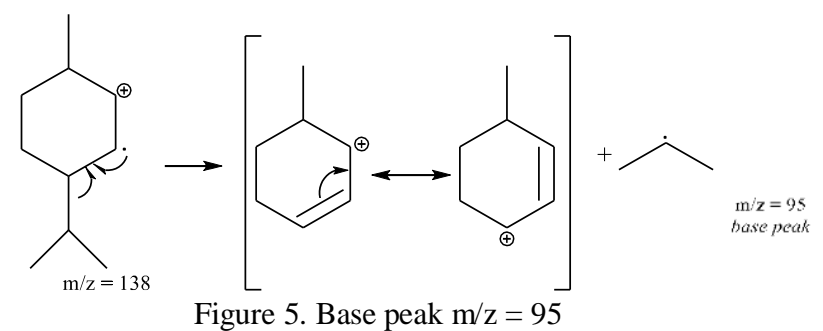

Besides the release of atom $O$ at position $\alpha$ is shown in Figure 6 with $\mathrm{m} / \mathrm{z}=43$ obtained result that are spesific termination ester.

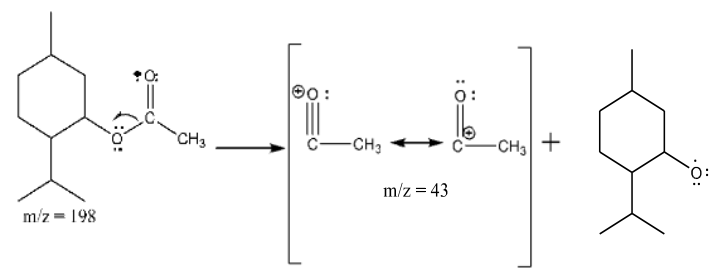

Figure 6. Leaving on $\alpha$ position

\section{CONCLUSION}

Variation of time influence yield of $l$-methyl acetic $88,43 \%$ with optimum time is 90 minutes and characterization of the product $l$ - methyl acetic by monitoring TLC result obtained $\mathrm{R}_{\mathrm{f}}$ which was0,41 is $l$ - menthol and $\mathrm{R}_{\mathrm{f}}$ which was 0,82 is $l$-methyl acetic. FTIR results with typical absorption of functional groups $\mathrm{C}=\mathrm{O}$ and $\mathrm{C}-\mathrm{O}$ ester at wave number $1736,96 \mathrm{~cm}^{-1}$ and $1245,82 \mathrm{~cm}^{-}$. Results chromatogram GC with a value $\operatorname{tr}_{\mathrm{r}}$ which was 14,82 minutes is $l$-methyl acetic. GC-MS results with $\operatorname{tr}_{\mathrm{r}}$ which was 16,13 minutes is $l$-methyl acetic.

\section{REFERENCES}

Bulan, R. (2004). Esterifikasi Patchouli Alkohol Hasil Isolasi dari Minyak Daun Nilam (Patchouli Oil). Sumatera Utara: USU Digital Library. 
Carey, F.A. (2000). Organic Chemistry, Fourth Edition. New York: McGraw Hill.

Chasana, N. U., R. Retnowati dan Suratmo. (2014). Eterifikasi 1-mentol dan Anhidrida Asetat dengan Variasi Mol Reaktan. Kimia Student Journal. 1(2),276-283.

Chasana, N.U., R. Retnowati dan Suratmo. (2014). Esterifikasi l-2-isopropil-5- metilsiklo-heksanol ( $l$-mentol) Menggunakan Asetat Anhidrida dan Uji Hedoniknya Berdasar Tingkat Kesukaan. Skripsi Tidak Diterbitkan. Malang: FMIPA Universitas Brawijaya.

Fatmawati, D. dan P. D. Shakti. (2013). Reaksi Metanolisis Limbah Minyak Ikan Menjadi Metil Ester sebagai Bahan Bakar Biodiesel dengan Menggunakan Katalis $\mathrm{NaOH}$. Jurnal Teknologi Kimia dan Industri. 2(2), 68-75.

Hikmah, M.N, Zuliyana. (2010). Pembuatan Metil Ester (Biodiesel) dari Minyak Dedak dan Metanol dengan Proses Esterifikasi dan Transesterifikasi. Skripsi. Fakultas Teknik, Universitas Diponegoro, Semarang.

Kasim, R. (2012). Disain proses dua tahap esterifikasi-transesterifikasi (estrans) pada pembuatan metil ester (biodiesel) dari minyak jarak pagar (Jatropha curcas,L). Tesis. Bogor: Program Pasca Sarjana, Institut Pertanian Bogor.

Pelter; S.W. Libbie; A. Amico; N. Gordon; C. Martin; D. Sandifer; W.M. Pelter. (2008). Analysis of Pepermint Leaf Extract by Thin-Layer Chromatography. Journal of Chemical Education. 85(1), 131 - 13/

Raharjo, T. J. (2013). Kimia Hasil Alam. Yogyakarta: Pustaka Pelajar.

Sastrohamidjojo, H. (2004). Kimia Minyak atsiri. Yogyakarta: Gajah Mada. University Press.

Silverstein, R.M.; X. W. Francis; J. K. Davis. (2005). Spectrometric Identification of Organic Compound, $7^{\text {th }}$ Edition. USA: Jhon Willey and Sons Inc.

Stolle, A.B.O. dan H. Hopf. (2009). Thermal Rearrangement of Menotherpenes and Monoterpenoids. Institut for Technical Chemistry and Environmental Chemistry. Friedrich-Schiller University Jena. 